\title{
Authenticity as a Sustainable Value of Holistic Conservation: The Case of Turkey's World Heritage Sites ${ }^{1}$
}

\author{
Bütüncül Korumanın Sürdürülebilir Bir Değeri Olarak Özgünlük: \\ Türkiye’nin Dünya Miras Alanları Örneği
}

\author{
Özlem KARAKUL
}

The discussions on 'authenticity' have always been central in conservation studies. Nowadays, in recent years, the discussions also continued within the debates on the conservation of intangible cultural heritage. This paper brings a new standpoint about 'authenticity', considering it as a value for conservation. Its subjective nature need to be minimized by the clear definition of its constitutive aspects including both tangible and intangible features. To make it more concretized, it needs to understand the decision makers on authenticity and to define it in current conditions of historic environments comparatively. Before the Nara Document on Authenticity, defining the concept of authenticity as "the essential qualifying factor concerning values", it had generally been explained as a quality regarding physical characteristics. The document determined the sources of information to be linked with authenticity including "form and design, materials and substance, use of function, traditions and techniques, location and setting, and spirit and feeling, and other internal and external factors". After this document, the relations between intangible values and authenticity have been tried to be defined more clearly. This study puts forward that the sustainability of the originality of integrity of both intangible and tangible values is significant for the accuracy of the holistic conservation of built heritage. The study mainly investigates two of Turkey's sites in the world heritage list (WHL), Archeological Site of Troy and City of Safranbolu, considering their outstanding universal value and the related criteria which they satisfied; and, the tangible and intangible aspects of their specific conditions of authenticity as outlined in the Nara Document on Authenticity comparatively. Keywords: Authenticity; intangible values; Safranbolu; tangible values; Troy; Turkey's world heritage sites.

"Özgünlük" kavramının koruma çalışmalarındaki öneminden yola çıkan bu çalışma, somut ve somut olmayan yönleriyle "özgünlük" kavramına ilişkin bütüncül bir yaklaşım ortaya koyarak, Türkiye'nin UNESCO Dünya miras listesinde yer alan alanlarını, bu yaklaşım çerçevesinde değerlendirmektedir. Bu çalışma, dünya miras listesindeki alanların, "üstün evrensel değerlerini" oluşturan kriterler ile Nara Özgünlük Belgesi'nde ortaya konulan, özgünlük kavramının farklı yönlerini birlikte ele alarak, özgünlüğün yalnızca fiziki değerler ile incelenmemesi gereğini vurgulamayı amaçlamaktadır. Nara Özgünlük Belgesi'nde ortaya konan kriterlerden, "biçim ve tasarım, malzeme ve madde, konum ve çevre", özgünlügün somut yönleri, "işlev kullanımı, gelenekler ve teknikler, ruh ve his"i ise özgünlüğün somut olmayan yönleri olarak ele alan bu çalışma, Türkiye'nin dünya miras alanlarının üstün evrensel değerlerini oluşturan kriterleri, özgünlüğü oluşturan yönleri açısından değerlendirererek bütüncül koruma çalışmalarına katkıda bulunmayı amaçlamaktadır. Yapılan bu çalışma, dünya miras alanlarının, somut ve somut olmayan değerlerini birlikte ele alarak, son yıllarda artan bütüncül koruma tartışmalarına önemli katkılarda bulunması amaçlanmaktadır. Çalışma Türkiye'nin dünya miras listesinde yer alan iki alan olarak Truva Arkeolojik Alanı ile Safranbolu kentini, üstün evrensel değerleri ve ilişkili kriterlerle birlikte, Nara Özgünlük Belgesi'nde ortaya konmuşözgünlüğün koşullarının somut ve somut olmayan yönlerini ele alarak incelenmektedir.

Anahtar sözcükler: Özgünlük; somut olmayan değerler; Safranbolu; somut değerler; Truva; Türkiye'nin dünya miras alanları.

'This paper is written by developing a conference presentation carried out by Karakul (2015) in REHAB 2015- $2^{\text {nd }}$ International Conference on Preservation, Maintenance and Rehabilitation of Historic Buildings and Structures, 22-24 July, Porto.

Selçuk University Faculty of Fine Arts, Konya, Turkey.

Article arrival date: August 04, 2015 - Accepted for publication: November 01, 2016

Correspondence: Özlem KARAKUL. e-mail: karakulozlem@gmail.com

๑ 2016 Yıldız Teknik Üniversitesi Mimarlık Fakültesi - ๑ 2016 Yıldız Technical University, Faculty of Architecture 


\section{Introduction}

Historic environments embody certain tangible and intangible values. The tangible values of environments are mainly composed of the physical structure made of built and natural structures, specifically, buildings, topographical and geological characteristics (Karakul, 2011a, 2011b). The intangible values of historic environments are mainly composed by cultural practices and expressions within the built environments, meanings expressed by them and values attributed to them (Karakul, 2011a, 2011b). The tangible and intangible values constituting the integrity of environments have continuously been interrelated through the different processes, like, formation and transformation processes. Thereby, this study proposes that the concept of authenticity is also a unity composed of tangible and intangible aspects; and, it need to be defined considering both of them accurately.

This paper deal with the relationship between authenticity and the tangible and intangible values of historic environments particularly focusing on Turkey's two world heritage sites. This study firstly makes a clear definition of tangible and intangible values in historic environments; and tries to associate with the term 'authenticity' conceptually. Secondly, to highlight tangible and intangible aspects of authenticity, it investigates the previous studies and the Nara Document. The tangible and intangible aspects of the term 'authenticity', which was investigated in the Nara Document, are categorized according to the previous conceptual definition of this study. A specific matrix to show the relationship between tangible and intangible aspects of authenticity and the UNESCO criteria for the assessment of sites with regard to their outstanding universal value is prepared. Finally, another matrix is used to show the relationship between Turkey's world heritage sites and their selection criteria highlighting the tangible and intangible aspects of authenticity. Using these two matrixes, two world heritage sites, Troy and Safranbolu, exhibiting the noticeably different integrities of tangible and intangible values with regard to their effects on the authenticity of the sites, are selected to investigate in more detail with the specific elements included particular to these sites in this study. In result, a discussion and evaluation is made to highlight and compare the aspects of authenticity of these two world heritage sites.

\section{Authenticity as a Value For Conservation}

The notion of authenticity has mainly been discussed with regard to the concepts of 'continuity' and 'change' and the notion of 'truth' over the years (Jokilehto, 2006b, 2). Considering the expansion/ meaning/ reflections of the "cultural diversity" as declared by UNESCO, Jokilehto (2006b) states that different cultures may certainly have the different ways of expressing themselves about issues such as truth and authenticity. The aspects of being truthful or authentic cannot be reduced to only physical or tangible; they also include the intangible aspects and all of the meanings attributed to physical beings. Thereby, first, the conservation of a physical work should be a process requiring understanding both of these issues. And second, cultural expressions should also be evaluated regarding their authentic/ genuine aspects for their conservation.

Before the Nara Document on Authenticity (1994) defining the concept of authenticity as "the essential qualifying factor concerning values", it had generally been explained as a quality regarding physical characteristics. The document determined the sources of information to be linked with authenticity including "form and design, materials and substance, use of function, traditions and techniques, location and setting, and spirit and feeling, and other internal and external factors". After this document, the relations between intangible values and authenticity have been tried to be defined more clearly; but, in 2004, the Yamato Declaration launched in a UNESCO expert meeting in Nara, stated that the term of authenticity could not be applied in the same way and is not relevant when assessing intangible cultural heritage because of its constant recreation. Supporting to the statement determined on that meeting, the UNESCO Sub-Regional Capacity-Building Workshop in 2008 also re-stated and emphasized the incompatibility of authenticity with the viability of intangible cultural heritage. At the same time, the previous parameters in the Nara Document have been diversified as "the conditions of authenticity" also including the different aspects of culture, namely, "traditions, techniques, language and other forms of intangible heritage as well as spirit and feeling" in the operational guidelines launched by UNESCO.

Evaluating previous studies, Jokilehto (2006a) clarifies authenticity with regard to its relationships with three issues: the "creative process, the documentary evidence and the social context". Jokilehto (2006a) also elucidates the social context with the intangible dimension of heritage, the know-how and skills, as stressed in the UNESCO 2003 Convention on intangible heritage and some national laws. This approach represents a synthesis of Nara Document for its presentation of tangible and intangible aspects of authenticity.

Enriching cultural properties, the term of "authenticity" represents one of their values to be conserved. Feilden and Jokiletho $(1998,16)$ identify authenticity as an attribute to be "ascribed to a heritage resource that is materially original or genuine as it was constructed and as it has aged and weathered in time". They also explain "being 'authentic' in relation to the creative process that produced it as a genuine product of its time, and includes the effects of 
its passage through historic time" (Feilden and Jokiletho, 1998, 16).

Arising from the previous studies on authenticity, this study try to highlight the tangible and intangible aspects of authenticity conceptually and practically with the concrete examples from the world heritage sites of Turkey. This study categorizes the conditions of authenticity determined in the Nara Document in two groups as tangible and intangible aspects to evaluate them with the criteria of outstanding universal value for the selection of world heritage sites. From the conditions of authenticity determined in the Nara Document, "form and design, materials and substance, location and setting are handled as the tangible aspects of authenticity; and, use or function, traditions and techniques, and spirit and feeling are handled as the intangible aspects of authenticity by this study.

\section{Authenticity as a Criterion for World Heritage Sites}

After the 1972 World Heritage Convention', the definition of cultural heritage has been expanded to include intangible cultural heritage besides natural and built heritage. UNESCO has also emphasized the need to recognize cultural diversity and intangible cultural heritage to conserve as cultural heritage ${ }^{i i}$. In the Operational Guidelines for the Implementation of the World Heritage Convention, UNESCO determines ten criteria for the assessment of sites with regard to their outstanding universal value to form world heritage listiii. World heritage sites need to satisfy at least one of ten criteria besides the conditions of authenticity, and, to have "outstanding universal value" (Jokilehto, 2006a). This study mainly investigates Turkey's world heritage sites with regard to their outstanding universal value and the related criteria which they satisfied; and, the tangible and intangible aspects of their specific conditions of authenticity as defined in the Nara Document on Authenticity.

\section{World Heritage Sites in Turkey}

Turkey has 16 sites in the world heritage list, prepared according to 1972 UNESCO World Heritage Convention by the World Heritage Committee today. Because the analyses of this study were carried out before $2015^{2}$, the study focuses on 13 of them which are (1) Archeological Site of Troy; (2) Bursa and Cumalıkızık: the Birth of the Ottoman Empire; (3) City of Safranbolu ; (4) Great Mosque and Hos-

UNESCO. (1972). Convention Concerning the Protection of the World Cultural and Natural Heritage. 17th Session of the General Conference. November 16 . Paris

UNESCO. (2003). Convention for the Safeguarding of the Intangible Cultural Heritage. 32nd Session of the General Conference. September 29- October 17. Paris. Retrieved December 23, 2004, from http://unesdoc.unesco.org/ images/0013/001325/132540e.pdf

iii See http://whc.unesco.org/en/criteria/

2 Diyarbakır Fortress and Hevsel Gardens Cultural Landscape (2015), Ephesus (2015), Archaeological Site of Ani (2016) are not evaluated within the scope of this study, because matrixes were prepared before 2015. pital of Divriği; (5) Hattusha: the Hittite Capital; (6) Historic Areas of Istanbul; (7) Nemrut Dağ; (8) Neolithic Site of Çatalhöyük; (9) Pergamon and its Multi-Layered Cultural Landscape; (10) Selimiye Mosque and its Social Complex; (11) Xanthos-Letoon; (12) Göreme National Park and the Rock Sites of Cappadocia (13) Hierapolis-Pamukkale.

After the evaluations of the data in two matrixes shown above (Table 1 and Table 2), because of exhibiting the noticeably different integrities of tangible and intangible values with regard to their effects on the authenticity of the sites, two world heritage sites, Troy and Safranbolu were selected to investigate their outstanding universal value and the related criteria determined by the World Heritage Committee; and to highlight the tangible and intangible aspects of their specific conditions of authenticity comparatively.

\section{Archaeological Site of Troy}

Troy, known as Troas in the ancient period, is located within the boundaries of Biga Peninsula in the region of Marmara (Aslan, 2016, 253). The world heritage committee decided to inscribe Troy in 1998 on the basis of: criteria ii, iii, vi determining its outstanding universal value. Exhibiting a more than 3000-year history of settlement and civilization, Troy was decided to meet the criterion ii (Aslan, 2016, 252). Acting as a cultural bridge between the Troad region and the Balkans, Anatolia, Aegean and Black Sea regions through migrations, occupations, trade and transmission of knowledge and providing characteristic examples of an ancient oriental city in an Aegean context, it was decided to fulfill the criterion iii (Aslan, 2013). As a setting for Homer's The lliad, and Virgil's The Aeneid, which have provided lasting inspiration on the creative arts for over more than two millennia, Troy was also decided to meet the criterion vi (Aslan, 2013). These values of Troy contribute to its authenticity with regard to the form and design of the buildings included, its location and setting as tangible aspects; and, traditions and techniques creating buildings, spirit and feelings aroused in people as intangible aspects.

\section{Tangible Aspects of Authenticity}

Troy has a significant place among the world heritage sites with regard to the dominancy of its intangible aspects defining its authenticity. Among the limited number of tangible heritage elements, the form and design of the ruins and archaeological information obtained through time have provided to describe the original period and the different layers formed through time.

\section{Form\&Design}

As a continuous settlement for 3000 years, the ruins in Troy give valuable information about the form and design of the buildings which built in different periods by differ- 
Table 1. A matrix showing relations between criteria and the aspects of authenticity

\begin{tabular}{|c|c|c|c|c|c|c|c|c|}
\hline & & CRITERIA FOR & TANG & 3LE ASPE & & INTANGIE & E ASPEC & \\
\hline & & DUTSTANDING UNIVERSAL VALUE & $\begin{array}{l}\text { FORM\& } \\
\text { DESIGN }\end{array}$ & $\begin{array}{l}\text { MATERIAL\& } \\
\text { SUBSTANCE }\end{array}$ & $\begin{array}{l}\text { LOCATION } \\
\text { \& SETTING }\end{array}$ & $\begin{array}{l}\text { TRADITIONS\& } \\
\text { TECHNIQUES }\end{array}$ & $\begin{array}{l}\text { USE\& } \\
\text { FUNCTION }\end{array}$ & $\begin{array}{l}\text { SPIRIT\& } \\
\text { FEELING }\end{array}$ \\
\hline & $\bar{i}$ & to represent a masterpiece of human creative genius & • & • & & - & & \\
\hline & ii & $\begin{array}{l}\text { to exhibit an important interchange of human values, over a span of } \\
\text { time or within a cultural area of the world, on developments in } \\
\text { architecture or technology, monumental arts, town-planning or } \\
\text { landspace design; }\end{array}$ & • & & $\bullet$ & • & & \\
\hline & iii & $\begin{array}{l}\text { to bear a unique or at least exceptional testimony to a cultural tradition } \\
\text { or to a civilization which is living or which has disappeared; }\end{array}$ & & & - & & & $\bullet$ \\
\hline & \begin{tabular}{|l|} 
iv \\
\end{tabular} & $\begin{array}{l}\text { to be an outstanding example of a type of building, architectural or } \\
\text { technological ensemble or landscape which illustrates (a) signigicant } \\
\text { stage(s) in human history; }\end{array}$ & • & • & • & • & • & • \\
\hline 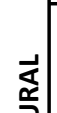 & $\begin{array}{ll}v \\
\end{array}$ & $\begin{array}{l}\text { to be an outstanding example of a traditional human settlement, land- } \\
\text { use, or sea-use which is representative of a culture (or cultures), or } \\
\text { human interaction with the environment especially when it has become } \\
\text { vulnerable under the impact of irreversible change; }\end{array}$ & $\bullet$ & & • & • & • & \\
\hline 卢 & vi & $\begin{array}{l}\text { to be directly or tangibly associated with events or living traditions, with } \\
\text { ideas, or with beliefs, with artistic and literary works of outstanding } \\
\text { universal significance. }\end{array}$ & & & & • & & • \\
\hline & \begin{tabular}{|l|} 
vii \\
\end{tabular} & $\begin{array}{l}\text { to contain superlative natural phenomena or areas of exceptional } \\
\text { natural beauty and aesthetic importance; }\end{array}$ & • & & - & & & • \\
\hline & viii & $\begin{array}{l}\text { to be outstanding examples representing major stages of earth's history, } \\
\text { including the record of life, significant, on-going geological processes in } \\
\text { the development of landforms, or significant geomorphic or } \\
\text { physiographic features; }\end{array}$ & • & & • & & & \\
\hline 工 & ix & $\begin{array}{l}\text { to be outstanding examples representing significant on-going ecological } \\
\text { and biological processes in the evolution and development of terrestrial, } \\
\text { fresh water, coastal and marine ecosystems and communities of plants } \\
\text { and animals; }\end{array}$ & & & • & & & \\
\hline 离 & $\mathrm{x}$ & $\begin{array}{l}\text { to be contain the most important and significant nutural habitats for in- } \\
\text { situ conservation of biological diversity, including those containing threat- } \\
\text { ened species of outstanding universal value from the point of view of sci- } \\
\text { ence or conservation. }\end{array}$ & & & • & & & \\
\hline
\end{tabular}

Table 2. A matrix showing the criteria for outstanding universal value of Turkey's world heritage sites and the aspects of authenticity

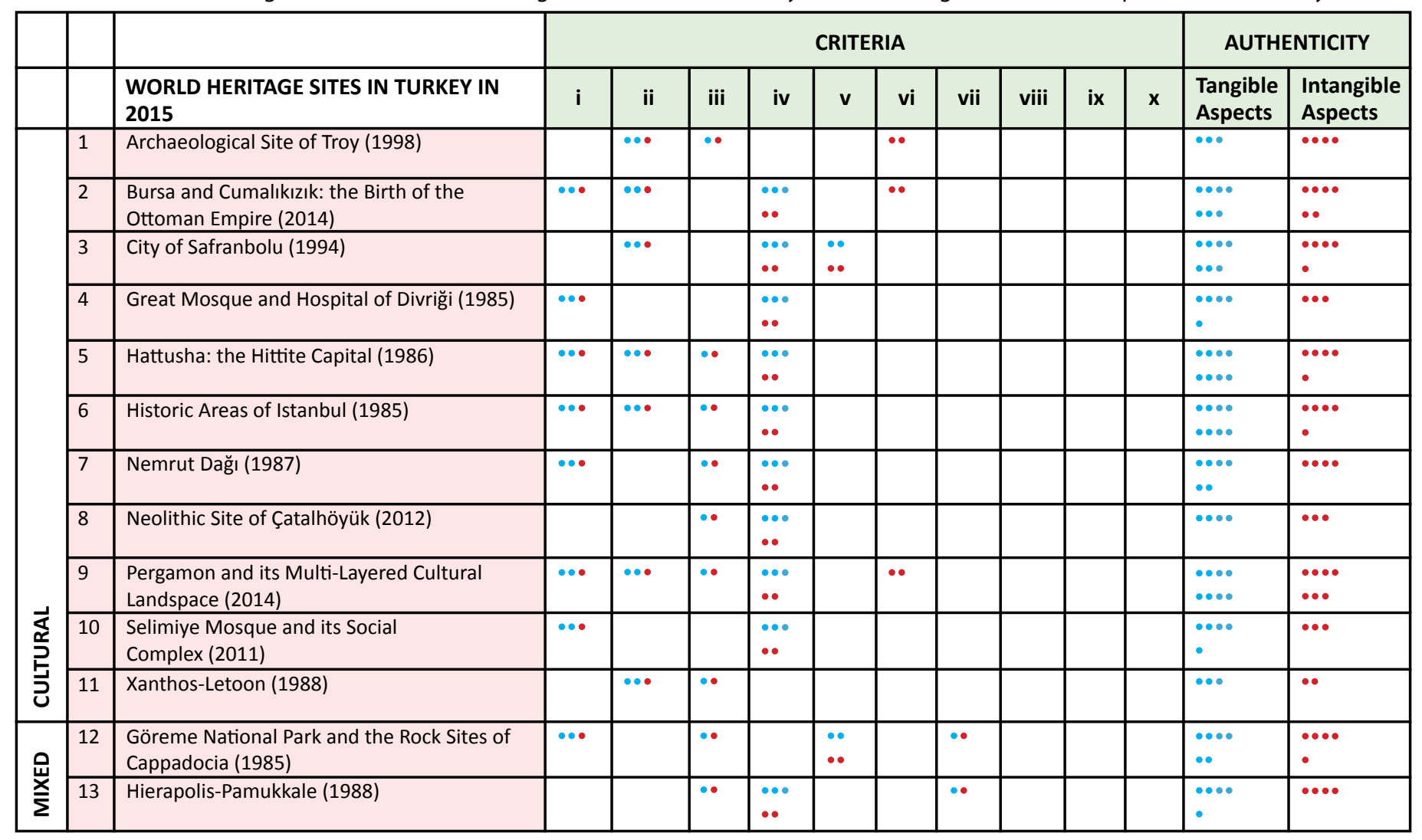


ent civilizations. Because of houses made of adobe, there are many layers of destruction found in the excavations. The artificial hill of Troy, which is 16 meters high, includes various findings of tangible properties of 10 different civilizations (Aslan, 2016, 261). Among them, the lowest seven layers of settlement at Troy, from Troy I to Troy VII, representing from Early Bronze Age to Eearly Iron Age include the ruins of more than 50 phases of construction. The layer of Troy VIII consists of the ruins dated to ancient Greece. Troy IX includes the ruins of the Roman city of Ilion; and, Troy $X$ consists of the ruins of Byzantine settlement and the following civilizations. Troy I has the ruins of adjacent buildings with stone foundations and adobe walls and a strong defense system. Troy II, as a fortress settlement, included high towers and large megarons (rectangular buildings with an entrance space and a main room) as a significant building type in architectural history, which were first built in this period. Troy VI, which is known as Homer's Troy, includes the ruins of magnificent castles and palaces. Troy VI consists of a great number of ruins of architecture, and findings of pottery, representing the transition to Iron Age. Troy IX known to be represented the Roman period includes the ruins of Athena Temple and the Great Amphitheater. Troy X (12-13 th century) included the ruins of Byzantine settlement and ended by Ottoman invasion (Aslan, 2016, 266).

\section{Location\&Setting}

Because of its location between East and West (Asia and Europe) and two seas (Black Sea and Aegean Sea) having a strategic significance, Troy has been settled since prehistoric times and has been a battleground in many wars (Aslan, 2016, 261). Its location is especially important for its being a setting of Trojan War which took place between 1250-1135 B.C and Homer's epics.

\section{Intangible Aspects of Authenticity \\ Traditions\&Techniques}

As a 3000-year continuous settlement, Troy has a great number of ruins embodying valuable information about the different traditions and techniques used in building and living practices. Because of the buildings being made of adobe, new settlements had been constructed by smoothing the underneath one. A limited number of the tangible findings give sufficient information about the building and living culture of Troy.

The first use of a fast potter's wheel, which dates back to Troy II period, is a sign of the development level of pottery in this period.

\section{Spirit\&Feeling}

Troy is a significant and sacred site for a great number of people from different cultures, especially, European culture, all over the world because it is believed as a setting of
Trojan War, narrated in Homer's Legends, Illiad and Odyssey (Aslan, 2016, 255). After Homer, the epic lliad, which was treated as one of the foundational texts of European culture and literature, was copied many times and transferred from generation to generation (Aslan, 2016, 255). Another thing increasing the spiritual importance of Troy is that Virgil's epic, the Aeneid (29-19 B.C) depicted Trojans as ancestors of the Romans (Aslan, 2016, 256).

The sacredness of Troy is also caused by the visits of many historical persons, travelers, soldiers and politicians through history. Some of visitors are the Persian King Xerxes in 480 B.C., Alexander the Great in 334 B.C., other Roman empherors, Hadrian and Augustus, Mehmed the Conqueror in 1462 (Aslan, 2016, 270).

\section{City of Safranbolu}

Safranbolu is a town located within the boundaries of Karabük, within the boundaries of Northwest Black Sea Region. The world heritage committee decided to inscribe Safranbolu in 1994 on the basis of: criteria ii, iv, v, determining its outstanding universal value. Being a typical Ottoman city surviving to the present day, exhibiting an interesting interaction between the topography and the historic settlement, having a key role in the caravan trade over many centuries, including the buildings and streets having illustrative architectural forms of their period, Safranbolu was decided to meet the criterion ii (Canbulat, 2016 , 224). Safranbolu was determined to meet the criterion iv for preserving its original form and buildings. Preserving its traditional townscape composed of distinct districts, marketplace, and vineyards, Safranbolu was decided to meet the criterion v. Meeting these criteria, Safranbolu satisfied the conditions of authenticity regarding the form and design of the buildings with their original materials, its specific location and setting as tangible aspects; and, traditions and techniques creating buildings and the continuity of the original uses of buildings and spirit and feelings as intangible aspects.

Safranbolu is a historical settlement which includes a great number of traditional dwellings besides monumental historic buildings. There are a great number of the traditional buildings of Safranbolu keeping their authenticity both physically and culturally. The authenticity of buildings are caused from both their physical qualities reflecting the building traditions of the different historical periods; and intangible values, considering their continuous uses, their embodiment of the construction techniques of the different periods.

\section{Tangible Aspects of Authenticity \\ Form\&Design}

Safranbolu presents a great variety of traditional buildings, including monumental buildings, public buildings and 
dwellings, embodying the life culture of different periods, especially Seljukid and Ottoman period (Figure 1). The thing making Safranbolu so special to be a world heritage site is its holistically conserved condition with all buildings, streets and settlement pattern in especially Çarşı District besides the continuation of life, living practices, traditional craftsmanships in spite of the negative effects of tourism. After the beginnings of 1990s, in which certain residences were bought, restored and used as hotels, Safranbolu became acquainted with tourism (Canbulat, 2016, 225) (Figure 2).

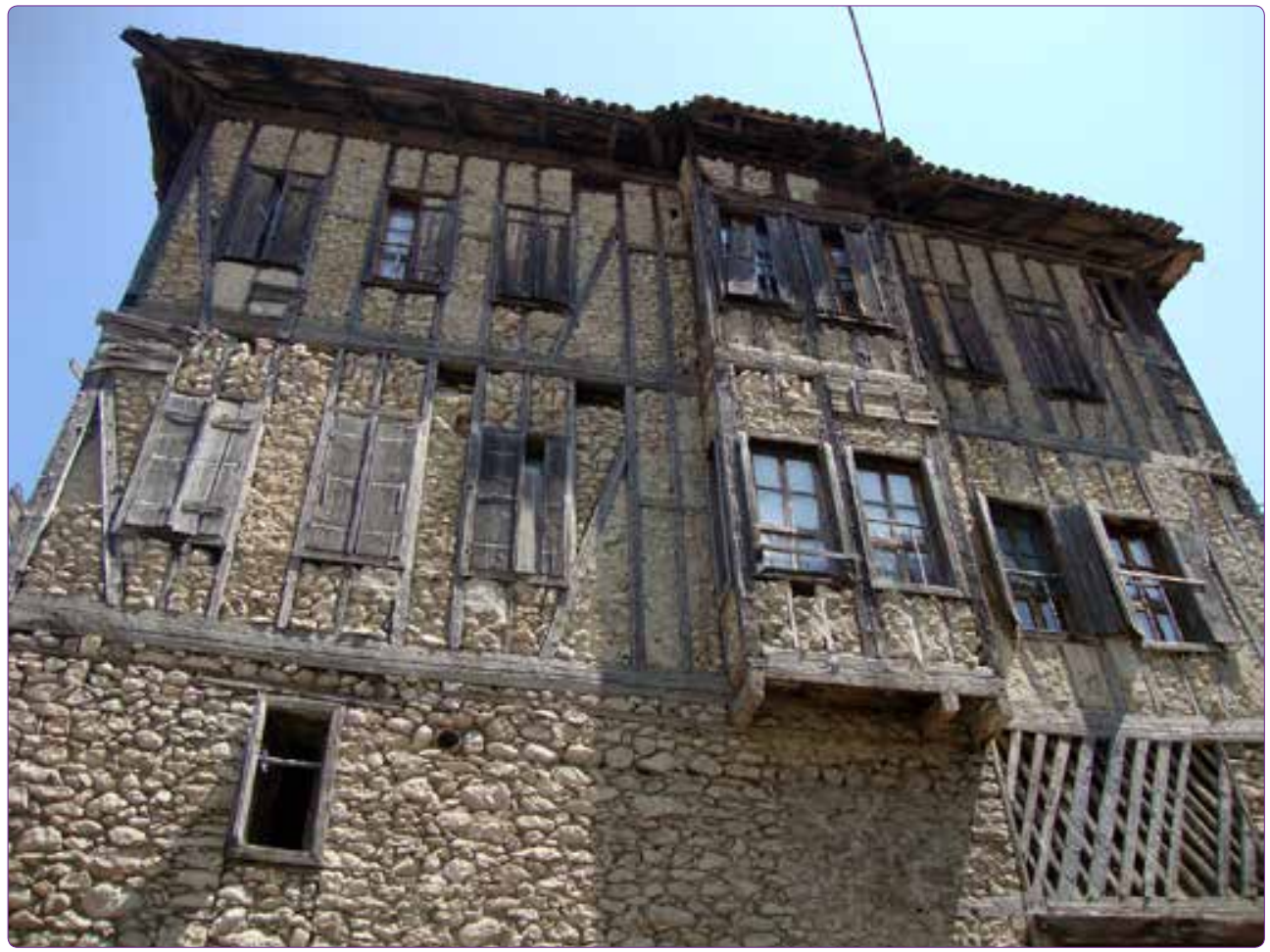

Figure 1. A traditional timber framed building with stone infill in Safranbolu.

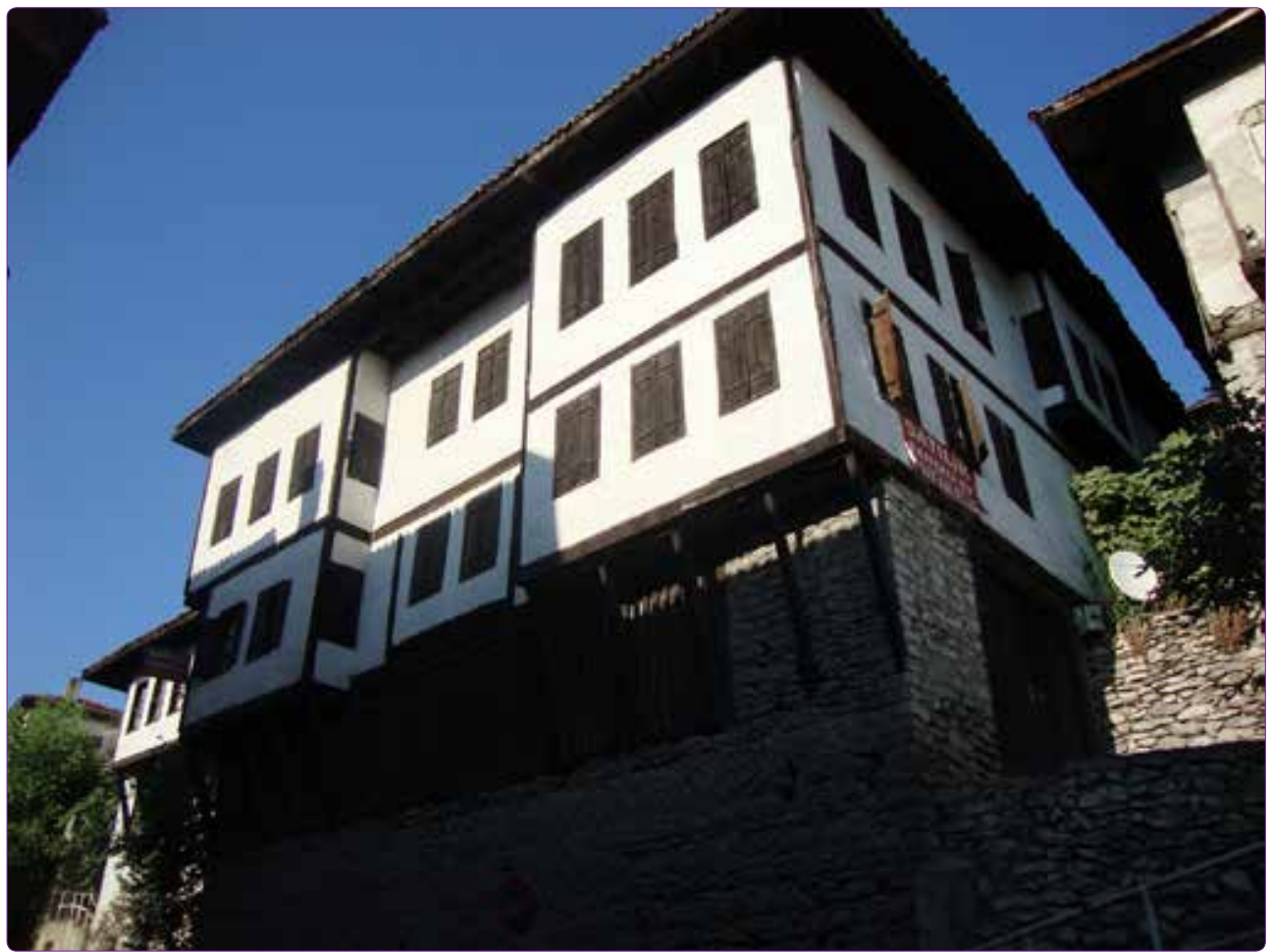

Figure 2. A restored traditional building in Safranbolu. 
The traditional buildings of Safranbolu have a significant place within the tradition of timber-framed houses in Anatolia which first appeared in the medieval and early Ottoman period (Şahin-Güçhan, 2007, 842). Traditional Safranbolu houses were built with timber frame construction system over a stone masonry ground floor (Günay, 1999, 136). The settlement of the traditional buildings on slopes provides sufficient light and view and privacy for them (Canbulat, 2016, 237).

The clock tower in Safranbolu which was constructed by Izzet Mehmet Pasha, is the oldest known clock tower of Anatolia (Canbulat, 216, 237).

\section{Material\&Substance}

The traditional buildings of Safranbolu were constructed by "hımış" technique, composed of timber frame skeleton system with stone masonry walls on ground floors and foundations. Safranbolu includes a great variety of buildings constructed by hımış technique. The continuity of building tradition is one of the significant physical features contributing the authenticity of the city.

\section{Location\&Setting}

Safranbolu's location is especially significant because of its being the eastern tip of Ottoman lands and the residence of nomads leaving from Asia (Canbulat, 2016, 225). The settlement characteristics of Safranbolu is thought to show the characteristics of Seljukid and Ottoman city, namely, dead-end-street, location on slope and organic planned building-street relations (Canbulat, 2016, 230). It also exhibits the Ottoman city characteristics with regard to organic street structure and composition of building units based on neighborly relations (Canbulat, 2016, 237) The new settlements of Safranbolu are formed in the canyon composed of Akçasu stream to the east of Citadel showing typical Ottoman city characteristics (Canbulat, 2016, 231)

\section{Intangible Aspects of Authenticity \\ Traditions\&Techniques}

Besides the building traditions, Safranbolu embody various craftsmanships, like the production of high quality Yemeni (light, flat-heeled shoes), saddlery, packsaddles, shoemaking and similar productions (Canbulat, 2016, 232, 247). Among from them, only shoemaking has still been continued as a handicraft in Safranbolu.

\section{Use\&Function}

Safranbolu can still be as a living city with the limited number of original users and a great number of people dealing with tourism in the traditional buildings at the center of old marketplace. From this respect, considering the intangible values of its authenticity, Safranbolu is noticeably different from Troy.
The rapid development of tourism has created a big threat for the quality of being a "Living City" which one of the most important reasons for its being on the UNESCO World Heritage List.

In spite of high number of residences and residential uses, Safranbolu is also significant because of being an "industrial city" prior to industrialization (Canbulat, 233).

\section{Spirit\&Feeling}

Besides the special physical characteristics of the traditional buildings, their unity defining the settlement characteristics and dramatically exhibiting the characteristics of Ottoman and Seljukid city, which create an appearance of Living city, arouse various feelings and spirit both for inhabitants and tourists.

\section{Evaluation and Discussion and Conclusions}

The study determined that the holistic conservation needs to continue the authenticity of the sites taking into consideration both tangible aspects, like, buildings, open areas, materials, and intangible aspects, like traditions, techniques, uses, spirit and feelings. This study tried to clarify the term 'authenticity' by categorizing the specific conditions of authenticity in the Nara Document as tangible and intangible aspects. The study demonstrated that authenticity cannot be determined considering not only physical characteristics; it also needs to consider the intangible aspects of the sites strongly.

Emphasizing the significance of the integrity of tangible and intangible values for guaranteeing the authenticity of the world heritage sites, the study evaluates Turkey's two world heritage sites, Troy and Safranbolu, considering their criteria determining outstanding universal value decided by World heritage Committee. Evaluating the selection criteria for world heritage sites and the Nara Document of Authenticity, the study tried to demonstrate that intangible values are as equally influential as tangible values in determining the authenticity of the sites.

The study showed that Troy and Safranbolu were noticeably different with regard to their integrity constituted by tangible and intangible elements defining their authenticity. According to the evaluation of UNESCO criteria considered for their being world heritage sites and the authenticity criteria highlighted in the Nara Document, although the tangible properties contributing to the authenticity of Troy are very limited, there are a huge number of publications documenting the form and design of building and settlement characterictics. In contrast to tangible aspects, Troy has a great values of its intangible heritage as a place of Trojan War and Homer's epic.

Safranbolu is different from Troy with regard to tangible and intangible aspects contributing to its authenticity. Known and defined as a 'Living City', Safranbolu is relative- 
ly so specific place conserved holistically with tangible and intangible properties despite of changes created by tourism. In especially Çarşı District, traditional settlement pattern and buildings are conserved physically on a large scale despite of changes in original functions due to tourism.

\section{References}

Agency for Cultural Affairs in cooperation with UNESCO, ICCROM and ICOMOS. (1994) The Nara Document on Authenticity, Nara Conference on Authenticity in Relation to the World Heritage Conven-tion. November 1-6. Nara, Japan, (Retrieved May 1, 2015, from http:// whc.unesco.org/document/9379).

Aslan, R. 2016. "Archeological Site of Troy", In Ertürk N., Karakul, Ö. (eds.), Unesco World Heritage in Turkey 2016, Ankara: Grafiker Yayıncılık. p. 253-274.

Canbulat, I. (2016) "City of Safranbolu”, In Ertürk N., Karakul, Ö. (eds.), Unesco World Heritage in Turkey 2016, Ankara: Grafiker Yayıncllık, p. 225-247.

Feilden, B.M., Jokilehto, J. (1998) Management Guidelines for World Cultural Heritage Sites. IC-CROM, Rome.

Günay R. (1999) Türk Ev Geleneği ve Safranbolu Evleri. Yapı Endüstri Merkezi Yayınları, İstanbul.

Jokilehto, J. (2006a) “World Heritage: Defining the Outstanding Universal Value", City\&Time 2 (2): 1-10.

Jokilehto, J. (2006b) "Considerations on authenticity and integrity in World heritage Context". City \& Time, 2, 1, 1, Retrieved September 2, 2016, from http://www.ct.ceci-br.org

Karakul, Ö. (2015) "Authenticity as a Sustainable Value of Holistic Conservation", REHAB 2015 - 2nd International Conference on Preservation, Maintenance and Rehabilitation of Historic Build-ings and Structures, 22-24 July, Porto.

Karakul, Ö., (2011a), "An Integrated Approach To Conservation Based On The Interrelations Of Tan-gible And Intangible Cultural Properties", METU Journal of The Faculty of Architecture, Vol: 28, No:2, p. 105-125.
Karakul, Ö. (2011b) A Holistic Approach to Historic Environments Integrating Tangible and In-tangible Values Case Study: İbrahimpaşa Village in Ürgüp, Unpublished PhD thesis, Department of Architecture, METU.

Şahin-Güçhan, N. (2007) Observations on earthquake resistance of traditional timber-framed houses in Turkey. Building and Environment, 42, 840-851.

UNESCO (2012) Operational Guidelines for the Implementation of the World Heritage Convention. Intergovernmental Committee for the Protection of the World Cultural and Natural Heritage, World Heritage Center. (Retrieved May 20, 2015, from http://whc.unesco.org/archive/opguide12-en.pdf)

UNESCO (2008) Sub- Regional Capacity- Building Workshop on the Implementation of the Convention for the Safeguarding of the Intangible Cultural Heritage. March 27-28. Pretoria, South Africa. (Retrieved May 20, 2015, from http://www. unesco.org/culture/ich/doc/src/00342-EN.doc)

UNESCO and the Japanese Agency for Cultural Affairs (2004) Yamato Declaration on Integrated Approaches for Safeguarding Tangible and Intangible Cultural Heritage. International Conference on the Safeguarding of Tangible and Intangible Heritage. October 20-23. Nara, Japan. (Retrieved May 1, 2015, from http://portal.unesco.org/culture/en/ files/23863/10988742599Yamato_Declaration.pdf/Yamato_ Declaration.pdf)

UNESCO (2003) Convention for the Safeguarding of the Intangible Cultural Heritage. 32nd Ses-sion of the General Conference. September 29-October 17. Paris. (Retrieved December 23, 2004, from

http://unesdoc.unesco.org/images/0013/001325/132540e.pdf) UNESCO (1972) Convention Concerning the Protection of the World Cultural and Natural Her-itage. 17th Session of the General Conference. November 16. Paris. (Retrieved April 14, 2008, from http://whc.unesco.org/archive/conventionen.pdf) 